\title{
Legong Dan Kebyar Strategi Kreatif Penciptaan Tari
}

\author{
Ni Nyoman Sudewi ${ }^{1}$, I Wayan Dana ${ }^{2}$, I Nyoman Cau Arsana ${ }^{3}$
}

Jurusan Seni Tari, Fakultas Seni Pertunjukan, Institut Seni Indonesia Yogyakarta

${ }^{2}$ iwayan_dana@yahoo.com

\begin{abstract}
Artikel ini bertujuan untuk memaparkan sebuah strategi penciptaan tari yang menempatkan dua genre tari Bali yaitu Legong dan Kebyar sebagai sumber inspirasi. Legong, sering disebut Legong Keraton, adalah genre tari yang muncul sekitar abad XIX. Genre tari ini mengusung konsep estetika bentuk dan struktur yang secara keseluruhan disebut seni palegongan. Sementara Kebyar yang muncul pada awal abad XX, menunjuk pada pembaruan garap tabuh atau karawitan Bali yang membawa suasana baru dalam kehidupan seni pertunjukan Bali dalam konteks kreativitas seni demi kenikmatan estetis maupun untuk mendukung berbagai kepentingan sosial keagamaan. Dilihat dari struktur dan ragam geraknya, struktur dan ragam gerak Kebyar menunjukkan adanya kemiripan dengan Legong. Kedua genre tari tersebut dalam perkembangannya masing-masing menemukan kekhususannya, dan berpeluang untuk dipertemukan, serta dijadikan sumber inspirasi penciptaan tari. Dalam memanfaatkan keduanya sebagai sumber garap tari, tentu memerlukan suatu metode dalam pengertian tahapan proses kreatif tertentu. Metode yang dicoba untuk diterapkan adalah memadukan tiga metode penciptaan yaitu: pertama, konsep angripta sasolahan meliputi ngarencana, nuasen, makalin, nelesin, dan ngebah; kedua, menerapkan teori $3 \mathrm{~N}$ yang dikemukakan oleh Ki Hajar Dewantara meliputi nitheni, niroke, dan nambahi; serta ketiga, menerapkan metode dan tahapan proses eksplorasi, improvisasi, dan komposisi serta evaluasi. Penerapan ketiganya secara simultan dalam tahapan proses penciptaan tari diyakini akan dapat mengarahkan setiap langkah kreatif untuk mencapai sasarannya. Di sisi lain, pemanfaatan tari tradisonal sebagai sumber penciptaan tari, akan berdampak pada revitalisasi, penguatan dan pengembangan nilai-nilai budaya lokal (Bali) yang biasanya menjadi acuan dalam berkesenian sekaligus hidup bermasyarakat.
\end{abstract}

Kata kunci: legong, kebyar, inspirasi, penciptaan tari

\section{Legong and Kebyar Creative Strategy Inspiration of Dance}

This paper aims at explaining a strategy for composing dance putting two Balinese genres, Legong and Kebyar, as the source of inspiration. Legong, generally called as Legong Keraton, is a Balinese dance genre that firstly exists in the nineteenth century. This genre carries the aesthetical concept of form and structure comprehensively called as the arts of palegongan. While Kebyar, which starts existing in the beginning of the twentieth century, shows the renewal of traditional Balinese ensemble music that brings about new atmosphere in the life of Balinese performing arts in the context of art creativity for aesthetic pleasure and for supporting social and religious interests. Focusing on the structure and range of motion, Kebyar structure and its range of motion show similarity with Legong. Both genres, in their historical development, each has found its specificity. However, Legong and Kebyar also have opportunity to be brought together, and to be utilized as the source of inspiration for composing dance.In utilizing both genres as the source of composing dance, it surely needs a method within the meaning of creative process stages. The method being tried to be applied is by integrating three methods of creating dance: first, applying the concept of angripta sasolahan consisting of ngarencana, nuasen, makalin, nelesin, and ngebah; second, applying Ki Hajar Dewantara's three-N theory consisting of nitheni, niroke, and nambahi; and third, applying the method and the processing stages of exploration improvization, composition, and evaluation. The application of the three methods simultaneously within the stages of creating dance will decisively be able to direct any creative steps for reaching the objective. On the other, the utilization of traditional dance as the source of dance creation will impact on the revitalization, the strength and the development of Balinese local culture that generally become the reference for artful life and community daily life.

Keywords: legong, kebyar, inspiration, creative strategy.

Proses Review : 1 - 20 Agustus 2019, Dinyatakan Lolos: 22 Agustus 2019 


\section{PENDAHULUAN}

Masyarakat luas, terutama mereka para penikmat budaya Bali, dapat dipastikan telah mengenal bahkan pernah menikmati keindahan Legong Keraton dan Kebyar, sebagai 'tampilan pewangi' dari hampir semua sajian seni wisata di Bali. Legong atau sering juga disebut Legong Keraton adalah sebuah genre tari yang kehadirannya telah melampaui rentangan waktu cukup panjang sejak diciptakannya yaitu pada sekitar abad XIX. Sebagai tari tradisi yang sarat makna filosofis dan estetis, genre tari Legong Keraton (diketahui ada sekitar 18 bentuk legong tradisi) dalam perwujudannya mengikuti konsep estetika bentuk dan struktur yang secara keseluruhan disebut seni palegongan. Selain menghadirkan dua penari putri berbusana kembar, aspek lain yang menandai konsep palegongan adalah penggunaan dan pengolahan properti kipas dalam seluruh bagian tari. Pengungkapan lakon atau cerita dari berbagai sumber, memberi penekanan pada pemunculan dua karakter secara abstrak simbolis dengan presentasi gerak dalam konsep estetika ngigelin gambelan. Konsep estetika ngigelin gambelan juga ada dalam kelompok tari Kebyar.

Kebyar muncul pada awal sekitar abad XX menunjuk pada pembaruan garap tabuh atau karawitan Bali. Akan tetapi, pada perkembangannya Kebyar juga berarti genre tari Kebyar yaitu sekelompok tarian yang mengusung konsep estetika tarian sebelumnya yaitu Legong (Sudewi, 2011: 464). Kehadiran genre Kebyar diperhitungkan membawa suasana baru dalam kehidupan seni pertunjukan Bali dalam konteks kreativitas seni demi kenikmatan estetis, juga untuk mendukung berbagai kepentingan sosial dan keagamaan (Pudjasworo, 1995/1996: 52-53). Struktur dan ragam gerak Kebyar menunjukkan kemiripannya dengan Legong. Pengungkapannya mengutamakan aksentuasi-aksentuasi gerak tari dan musik yang mengiringi senantiasa disinkronisasikan, seperti pada tari Legong yang menerapkan konsep estetika ngigelin gambelan. Namun demikian, keanekaragaman teknik dalam tari Kebyar telah menunjukkan tingkat sofistikasi tari dan tabuh. Tari Kebyar juga telah menemukan tema-tema baru untuk mengekspresikan berbagai pesan pada zamannya.

Dalam Legong, tema yang disampaikan berorientasi pada penyampaian konsep 'nilai dua', yang dihadirkan melalui tokoh dalam cerita atau dua karakter yang berbeda. Sementara dalam tari Kebyar, tema yang diusung sangat beragam dengan cakupan nilai yang berbeda-beda. Tari tradisi, Legong dan Kebyar, merupakan kekayaan budaya yang perlu dipertahankan eksistensinya, karena memiliki kandungan makna dan nilai-nilai kearifan lokal yang dapat dijadikan salah satu sumber inspirasi serta acuan bagi masyarakat maupun seniman pencipta tari dalam mengembangkan tari tradisi setempat. Semangat menjaga tradisi yang dimiliki tidak serta merta kemudian menutup hadirnya sesuatu yang 'baru' sesuai jiwa jamannya. Perubahan eksternal yang membawa serta nilai-nilai baru, meski kadang-kala tidak sejalan dengan nilai-nilai tradisi lokal, tetap diberi peluang hidup, karena dipandang dapat mewadahi semangat dan energi kreatif generasi muda dalam mengekspresikan dirinya. Hal ini pada akhirnya menjadi nilai tambah bagi meningkatnya apresiasi seni masyarakat, yang dengan demikian akan memperkokoh kecintaan terhadap seni tradisi miliknya.

Legong dan Kebyar laksana 'kakak dan adik' yang dalam pertumbuhannya masing-masing menemukan kekhususannya, dan tentu terbuka juga peluang untuk dipertemukan. Kedua tarian tradisi ini dijadikan sumber inspirasi untuk melahirkan tari-tarian 'baru' yang tumbuh subur dan berkembang hingga pelosok Pulau Bali maupun di kota-kota besar di Indonesia bahkan mancanegara. Bagaimana 'mempertemukan' dua yang berbeda sekaligus memiliki kesamaan sehingga menghasilkan dinamika dan satu kesatuan yang harmonis? Solusi terbaik dari pertanyaan kreatif atau permasalahan penciptaan ini adalah dengan mencoba menciptakan tari yang memadukan konsep estetika keduanya, Legong dan Kebyar. Dari pertanyaan kreatif ini dapat muncul beberapa pertanyaan ikutan yang menarik sehingga semakin menegaskan arah penciptaan tari, di antaranya:

1. Bagaimana jika struktur dalam Legong diisi dengan gerak pola kakebyaran, atau sebaliknya struktur Kebyar diisi dengan pola gerak palegongan?

2. Bagaimana kalau penari putra memperagakan pola gerak palegongan yang cenderung lembut dalam pola garis lengkung dengan liukan yang memanjang?

3. Pola gerak seperti apa yang dapat menunjukkan karakter Legong dan Kebyar, yang memungkinkan dilakukan baik oleh penari putra ataupun putri?

4. Tema apa yang tepat disampaikan dalam koreografi yang memanfaatkan inspirasi estetika Legong dan Kebyar?

Tentu masih ada banyak kemungkinan pertanyaan kreatif lainnya yang akan muncul di saat menjawab pertanyaan-pertanyaan di atas, sehingga penciptaan tari yang bersumber dari Legong dan Kebyar mencapai tujuan maupun sasaran.

\section{METODE PENELITIAN-PENCIPTAAN}

Tahapan penerapan metode atau proses kreatif dalam penciptaan tari yang bersumber dari Legong dan Kebyar, dapat dijelaskan sebagai berikut.

Pertama, berpijak pada prinsip-prinsip seniman Bali yang tercakup dalam konsep angripta sasolahan (mencipta tarian) meliputi ngarencana (tindakan persiapan penciptaan karya meliputi proses penjelajahan dan renungan yang intens), nuasen (mulai proses awal tindakan penciptaan), makalin (pemilihan material ciptaan), nelesin (pembentukan dan penyempurnaan hasil akhir ciptaan), dan ngebah (penyajian perdana bentuk karya secara utuh) (I Made Bandem, 2017 dan I Ketut Suteja, 2018). Dalam proses 
penciptaan karya seni, I Wayan Dibia juga menunjukkan pinsip-prinsip penciptan yang tertuang dalam Panca Sthiti Angawi Sani. Ada lima tahap yang seyogyanya dilakukan oleh seorang pencipta seni meliputi ngawirasa (merasakan secara mendalam), ngawacak (membaca dokumen-dokumen yang relevan), ngarencana (merencanakan format penyajian), ngawangun (menuangkan konsep-konsep yang telah dihasilkan termasuk finalisasi semua aspek garapan), dan maedeng (melakukan penyajian hasil karya melalui prosedur produksi), wawancara dengan I Wayan Dibia di rumahnya, 16 Juli 2018).

Kedua, berkaitan dengan pengamatan dan penjelajahan terhadap objek sumber penciptaan, akan digunakan metode yang dikemukakan oleh Ki Hajar Dewantara, tentang penerapan teori $3 \mathrm{~N}$ yaitu nitheni (memperhatikan Legong dan Kebyar secara utuh), niroke (menirukan Legong dan Kebyar secara berulang), dan nambahi (mewujudkan kreasi dan inovasi sesuai kemampuan pencipta) (Uswatun Nurhayati, 2011). Nitheni memperhatikan perjalanan Legong dan Kakebyaran secara historis dari sumbernya di Bali maupun realitas sajiannya di dunia pergelaran. Pengamatan yang cermat pada kedua genre tari tersebut yang berkembang dewasa ini, menjadi pijakan awal 'pencarian'. Bentuk pencarian didukung dengan menyaksikan berulang-kali pertunjukan Legong dan Kebyar secara langsung maupun melalui VCD (Video Compact Disc). Tarian yang menjadi sumber inspirasi penciptaan secara spesifik dapat ditentukan misalnya pada garap tari Legong Bapang, Legong Lasem, Kebyar Duduk, dan Terunajaya. Niroke, mengikuti alur yang mengalir dari perkembangan bentuk dan struktur tari Legong maupun Kebyar dari masa ke masa hingga dewasa ini, sehingga mendapatkan pemahaman lebih luas. Niroke juga dapat dipahami sebagai mengimitasi, mempelajari teknik gerak Legong dan Kebyar untuk menemukan kemungkinan pengembangannya. Nambahi, menunjukkan bahwa pada tahap ini peneliti menghadirkan kreativitas, kreasi, dan pengembangan Legong dan Kebyar sesuai jiwa jaman setempat, melalui penciptaan karya 'koreografi baru'.

Ketiga, seiring dengan penerapan metode pertama dan kedua, maka dalam penciptaan tari dapat digunakan juga metode dan tahapan proses meliputi eksplorasi, improvisasi, dan komposisi serta evaluasi (Hawkins dalam Hadi, 2011: 70-81). Satu kesatuan metode ini digunakan tidak hanya ketika menjelajahi/menemukan pola-pola gerak, tetapi juga untuk semua aspek yang hadir membentuk keutuhan sebuah tari. Hal ini dipertimbangkan atas dasar bahwa pemahaman yang dimiliki masing-masing, sebagai berikut.

Eksplorasi dipahami sebagai suatu aktivitas penjelajahan terhadap objek atau fenomena yang menjadi sumber inspirasi kreatif penciptaan. Pada tahapan ini, penjelajahan diarahkan untuk menemukan aspek-aspek Legong dan Kebyar yang dapat dijadikan acuan garap. Pola gerak spe- sifik, struktur tari berdasar bagian-bagiannya, pola atau motif musik, dan properti lain yang kemungkinan dapat dikembangkan. Bersamaan dengan tahapan penjelajahan ini dilakukan pula proses imitasi gerak untuk menguasai keterampilan tari Legong dan Kebyar khususnya melalui pelatihan tari Legong Lasem, Legong Bapang, Kebyar Duduk, dan Terunajaya. Penguasaan keterampilan tarian ini lebih diperuntukkan bagi para penari yang akan menampilkannya dalam pementasan. Sementara itu, bagi para penari yang akan menarikan tari hasil ciptaan, maka proses ini lebih diarahkan pada pengenalan ketubuhan tari Bali, dan penyadaran akan bentuk dan pola gerak sehingga dalam proses kreatif selanjutnya dapat lebih menghargai temuan-temuan yang didapat.

Selanjutnya, improvisasi dapat diartikan sebagai pencarian dan penemuan gerak secara kebetulan atau spontan. Dalam proses penciptaan karya ini, improvisasi gerak diorientasikan untuk menemukan kemungkinan lain (baru) dari aspek-aspek Legong dan Kebyar yang sudah ditetapkan sebagai sumber inspirasi dan acauan garap tari. Dengan demikian, improvisasi yang dilakukan lebih bersifat terarah atau terpimpin. Disadari bahwa tahap improvisasi diutamakan untuk meningkatkan kemampuan peran penari. Dalam tahapan ini koreografer dapat bekerja mandiri ataupun bersama-sama para penari terpilih yang menarikan karya cipta. Keterlibatan penari secara intens dalam proses, eksplorasi, improvosasi, bahkan komposisi dan evaluasi, menjadi salah satu penentu keberhasilan penciptaan karya.

Komposisi dapat diartikan sebagai tahap pembentukan atau pengorganisasian bentuk. Pola-pola gerak yang didapat dari proses eksplorasi dan improvisasi, dirangkai dengan mempertimbangkan estetika bentuk seni palegongan-kakebyaran. Prinsip-prinsip bentuk seni yang di antaranya meliputi kesatuan, keseimbangan, kontras, repetisi, variasi, dan lainnya dapat dipertimbangkan sebagai parameter penilaian rangkaian gerak yang telah dikomposisikan (Hayes, 1955: 11-210; Smith, 1975, terj. Suharto, 1985: 67-76). Pengorganisasian bentuk, selain antar gerak, juga gerak dengan elemen pendukung lainnya seperti musik tari, rias-busana, dan tata rupa pentas.

Pada kenyataannya, ketiga metode dan tahapan proses ini (eksplorasi, improvisasi, dan komposisi), tidak bersifat hirarkis tetapi bolak balik atau tumpang tindih satu terhadap yang lainnya. Hal ini terjadi karena setiap langkah proses yang dilalui dalam proses penciptaan tidak luput dari penilaian atau evaluasi. Evaluasi atau penilaian, dilakukan secara terus menerus untuk mendapatkan kesesuaian antara konsep dan realisasi bentuk yang dihasilkan.

\section{PEMBAHASAN}

Di Bali khususnya dan di beberapa daerah pada umumnya, peta proses pembelajaran seni termasuk proses pen- 
ciptaan tari dilaksanakan di 3 (tiga) konteks utama yaitu: di lingkungan keluarga dan masyarakat lokal secara turun temurun, lembaga pendidikan formal, dan di lingkungan sanggar atau studio-studio pribadi. Proses awal pembelajaran seni dimulai di lingkungan keluarga dalam konteks kebutuhan ritual dan di tingkat banjar (dusun), serta lebih khusus lagi di lingkungan sekaa (perkumpulan atau organisasi kesenian). Di sanggar atau studio, proses pembelajaran seni dalam konteks ini lebih mengasah konsentrasi kekuatan keterampilan seni yang mengarah ke olah seni secara profesional dan anggota-anggotanya mencakup masyarakat lebih luas (I Wayan Dana, 2016). Di lembaga pendidikan formal seni seperti di SMK dan di perguruan tinggi seni, para siswa/mahasiswa lebih terfokus mempelajari bidang seni yang mereka pilih sesuai dengan skill (keterampilan) atau bakat dan kecerdasan pengetahuan yang dimilikinya berdasarkan tata aturan yang ditentukan. Konteksnya mengetengahkan proses pembelajaran seni secara terstruktur, sistematis, dan perpaduan pendekatan ekspresi, disiplin ilmu, dan multikultur. Bagi mereka yang merampungkan pembelajaran di tingkat SMK, ia dapat meneruskan ke jenjang pendidikan tinggi seni atau ia memilih memperdalam dan mengasah bakatnya di studio atau sanggar-sanggar seni yang dianggapnya memberi peluang untuk meningkatkan kiprah seninya dan memberi inspirasi pengembangana metode penciptaan seni.

Berkaitan dengan penciptaan, sangat disadari bahwa penciptaan seni rohnya adalah kreativitas. Dalam ajaran Hindu, kreativitas berhubung kait dengan spiritual. Oleh karena itu, setiap pencipta seni khususnya tari didasari oleh kemampuan spirit kepenarian, keterampilan penguasaan teknik, pola-pola gerak, dan karakteristik tari tradisional dengan baik. Dalam kaitan penelitian tentang penciptaan tari untuk mengokohkan sumber inspirasi kreatif dan olah ketubuhan serta penguasaan kepenarian, maka dilakukan pelatihan tari yang menjadi sumber kreatif, seperti Legong Bapang, Legong Lasem, Kebyar Duduk, dan Terunjaya. Keempat tarian tradisi ini dipilih dengan alasan keunikan masing-masing, baik dalam kekayaan gerak ataupun bangun struktur tarinya. Legong Lasem, oleh masyarakat Bali sering disebut sebagai Legong Keraton, mengusung tema tentang kehidupan warga puri atau keraton, yang dipandang memiliki struktur paling lengkap yaitu tujuh bagian. Sementara itu, Legong Bapang menunjukkan pola garap Legong yang paling sederhana dan dinamis, memiliki tiga bagian yang merupakan pengembangan dari satu bagian dalam struktur Legong yang lengkap. Di sisi lain, pemilihan tari Kebyar duduk dan Terunajaya dari kelompok Kebyar, selain karena penciptaannya pada periode awal kemunculan tari-tarian Kebyar, juga karena penggarapan tarinya menunjukkan kelekatan dengan elemen-elemen tari Legong.

Agar diperoleh gambaran secara komprehensif, sistematis, dan metodis, maka langkah strategis yang dilakukan dalam penciptaan tari dengan berbasis tari tradisi atau kebu- dayaan lokal, dilakukan dengan pola seperti berikut.

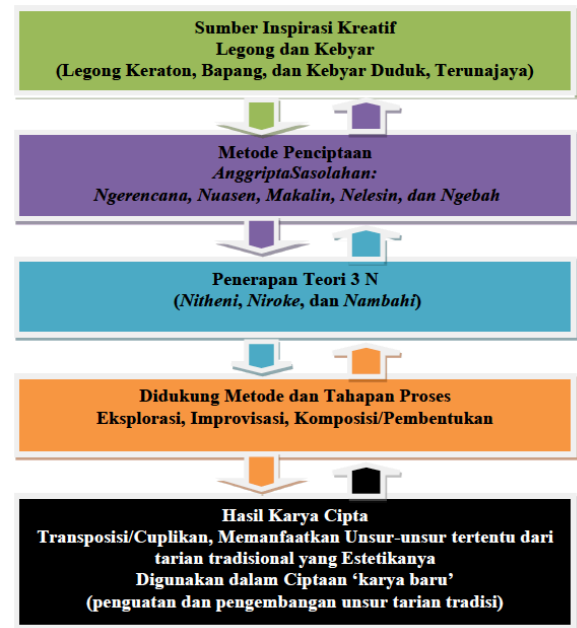

Proses penciptaan tari atau anggripta sasolohan diawali dengan tahap ngerencana. Ngerencana dilakukan sejak awal penjelajahan studi pustaka hingga menyaksikan, mengamati pergelaran Legong dan Kebyar sampai pada perenungan secara intens. Dalam teori Ki Hajar Dewantara, tahap ini disebut nitheni (memperhatikan secara historis dari sumbernya). Seorang peneliti/pencipta bersama para calon penari/pemain diajak menyaksikan sekaligus mengeksplorasi kemungkinan untuk menemukan pola gerak spesifik dari Legong Bapang, Lasem, Kebyar Duduk, dan Terunajaya. Tindakan pengamatan yang sungguh-sungguh dan eksplorasi dilakukan secara berulang baik melihat langsung pergelaran maupun tidak langsung keempat sumber inspirasi kreatif yang juga menjadi bagian makalin. Pengamatan ini menjadi pijakan awal 'pencarian' sehingga mampu meningkatkan penjelajahan sebuah pemancaran pemahaman estetis terhadap obyek yang diamati. Di saat pengamatan juga diadakan dialog antara koreografer/pencipta dengan para calon penari untuk mendalami hasil dari nitheni, sehingga terjadi kesamaan tentang pemahaman obyek genre palegongan maupun kakebyaran.

Tahap selanjutnya niroke (mengikuti alur yang mengalir dari perkembangan Legong dan Kebyar dari masa ke masa hingga dewasa ini), dengan metode imitasi atau teori menirukan secara seksama keempat tarian tradisi yang menjadi sumber inspirasi di atas. Dapat dilakukan melalui analisis gerak-struktur dari pakar atau seniman yang masih 'setia' menjaga 'keaslian' tarian itu. Niroke, penekanannya berkonsentrasi pada mengikuti atau meniru pola-pola gerak yang spesifik pada tarian Legong dan Kebyar dari masa ke masa hingga perkembangannya saat ini. Langkah ini dilakukan dengan mengundang para empu Legong dan Kebyar dari Bali, dihadirkan dalam workshop (di ISI Yogyakarta). Dengan proses ini dapat meningkatkan kualitas ketubuhan dan pemahaman ekspresi tari Bali masing-masing calon penari. Aktivitas niroke diharapkan memotivasi kerja aktif yang tanpa disadari secara otomatis menjadi ke- 
giatan yang mengasah ingatan para calon penari. Pengalaman menirukan secara utuh amat penting agar para calon penari mampu merasakan satu kesatuan antara objek dan subjek, sehingga memunculkan energi kreatif.

Tahap niroke ini menguatkan dan memantapkan keterampilan gerak para penari. Hal ini selaras dengan tindakan makalin yang mengutamakan proses pemilihan materi penari/pemain yang akan mendukung terciptanya karya tari. Pada proses ini, koreografer selaku peneliti, mengamati secara komprehensif keterampilan yang dimiliki oleh para pendukung khususnya calon penari. Kegiatan ini penting, karena penguasaan keterampilan dan kesungguhan para calon penari 'belajar menirukan' menjadi lebih 'terbuka' serta menyadari olah ketubuhan maupun kepenarian dengan baik. Melalui proses niroke gerak atau elemen lainnya dengan baik, menjadi salah satu dasar kekuatan bahwa 'bakal' (materi) yang bagus, ikut menentukan keberhasilan karya cipta.

Langkah berikutnya adalah nambahi, menunjukkan bahwa pada kerja tahap ini, peneliti/koreografer menghadirkan kemampuan kreativitas, kreasi, dan inovasi yang termotivasi dari tarian Legong dan Kebyar. Disadari bahwa kreativitas hadir tergantung atas kedalaman pengalaman koreografer untuk menggali ide, sumber inspirasi dari budaya penyangga Legong dan Kebyar sesuai jiwa jaman setempat. Pada tahap ini, pengalaman koreografer menyatu menjadi satu kesatuan sekala dan niskala atau jiwa dan raga. Kekuatan itu meletupkan improvisasi dan kreativitas yang menentukan munculnya inspirasi kreatif penciptaan. Dalam proses nambahi ini, koreografer merangkai, merangkum, dan menyusun seluruh hasil improvisasi pola-pola gerak serta semua aspek yang hadir membentuk keutuhan sebuah karya cipta kreasi yang kreatif sekaligus memberi 'ruang' untuk kemungkinan dievaluasi, dikembangkan, dan disempurnakan.

Tahap nambahi ini memiliki kedekatan yang kuat dengan nelesin yang artinya mengkomposisikan proses kerja karya cipta tari bersama para pemain. Aktivitas ini menunjukkan pengorganisasian atau perwujudan dan penyempurnaan serta penghalusan bentuk akhir karya tari yang diciptakan. Pada tahap ini bentuk ciptaan karya tari ditentukan agar terwujud menjadi satu kesatuan karakter gerak dengan musik tari, tata rias dan busana serta unsur lainnya sehingga menghadirkan kualitas bagi keutuhan komposisi tari. Tindakan nambahi merupakan tahap menentukan hasil terakhir dari proses penciptaan karya untuk dipersiapkan ke tahap ngebah yaitu pementasan perdana dari seluruh hasil transformasi keseluruhan kinerja penciptaan termasuk evaluasi.

Penerapan teori $3 \mathrm{~N}$ yang dikemukakan oleh Ki Hajar Dewantara (Uswatun Nurhayati, 2011) yang diselaraskan dengan prinsip-prinsip dalam anggripta-sasolahan (mencipta tari-tarian), dan 'dibungkus' dengan tahapan proses pen- ciptaan dalam konsep eksplorasi, improvisasi, dan komposisi (Hawkins dalam Hadi, 2011: 70-81), menunjukkan sebuah strategi penciptaan seni berkarakter nasional dalam arti menjaga sekaligus menguatkan kebudayaan lokal. Legong dan Kebyar merupakan tari tradisi yang memiliki identitas berbasis budaya Bali yaitu genre palegongan dan kakebyaran. Dengan demikian, strategi penciptaan tari ini lebih menekankan kekuatan transposisi atau cuplikan dari tarian tradisional yang diarahkan untuk revitalisasi (penguatan dan pengembangan) nilai-nilai budaya lokal yang menjadi identitas masyarakatnya. Penegasannya tampak bahwa unsur-unsur tertentu dari ungkapan tari tradisional (Legong dan Kebyar) dimanfaatkan dalam penciptaan tari 'baru' yang sangat terbuka terjadinya proses lintas budaya.

\section{SIMPULAN}

Legong dan Kebyar dapat dijadikan sumber inspirasi untuk melahirkan tarian Legong Kebyar 'kreasi'. Pemunculan berbagai kreasi tari di Bali khususnya, tidak serta merta memupus tari tradisional yang telah ada sebelumnya. Legong tradisi, legong kreasi, dan kreasi-kreasi tari Bali lainnya hidup berdampingan memenuhi kebutuhan masyarakat akan suguhan estetis yang sering juga mendatangkan keuntungan sisi ekonomis. Legong (Legong Keraton atau Lasem) pada awalnya merupakan jenis tari improvisatoris yang berpijak dari dramatari Gambuh, yang muncul sebelumnya. Legong, lebih lanjut menjadi inspirasi dan memicu lahirnya tarian Kebyar, yang akhirnya menemukan bentuknya hingga berkembang sampai sekarang. Dalam perkembangan selanjutnya gerak-gerak tarian Legong dan Kebyar mulai disesuaikan dengan musik pengiringnya, yaitu palegongan dan kakebyaran, sehingga menjadi tarian yang dinamis, indah, dan abstrak. Namun demikian, di balik ekspresi gerak-gerak indah dan abstrak itu terkandung ungkapan tarian yang bersifat energik dan dramatik atas dukungan para seniman pelaku maupun seniman pencipta beserta aktivitas masyarakat penyangga setempat.

Apresiasi, kreasi, dan inovasi para seniman, terutama koreografer dan komposer, terhadap tarian tradisional dengan satu upaya revitalisasi (penguatan dan pengembangan), tentu akan berdampak pada kelestarian budaya lokal dan pemanfaatannya lebih luas dalam berkehidupan. Di sisi lain, karya tari yang diciptakan berdasarkan hasil penelitian tentu akan memiliki akar dan orientasi yang lebih terarah, sistematis yang menunjukkan kekuatannya sebagai sebuah kreasi yang kreatif sekaligus memberi 'ruang' kemungkinan untuk dikembangkan kembali. Pengembangan memiliki 'roh' yang kuat terjadinya sesuatu perubahan mengarah ke bentuk yang 'baru' sesuai jiwa jaman setempat.

Penciptaan karya tari yang inspirasi kreatifnya bersumber dari karya sebelumnya (seperti Legong dan Kebyar) dapat disebut sebagai langkah transposisi. Langkah ini dapat 
dilakukan dengan cara memetik unsur-unsur tertentu dari karya yang diacu untuk dikreasikan menjadi sesuatu yang 'baru'. Langkah penciptaan tari seperti ini menunjukkan strategi penciptaan seni berkarakter nasional karena berbasis tarian tradisi, yaitu budaya lokal Bali dan bisa terjadi secara lintas budaya.

\section{DAFTAR PUSTAKA}

Bandem, I Made. "Metodologi Penciptaan Seni" dalam Yudiaryani, et al., (ed). Karya Cipta Seni Pertunjukan. Yogyakata: JB Publisher bekerja sama dengan FSP ISI Yogyakarta, 2017.

Gamelan Bali di Atas Panggung Sejarah. Denpasar: BP STIKOM Bali, 2013.

Dana, I Wayan., Ni Nyoman Sudewi, dan Bambang Pudjasworo. "Estetika Tari Bali: Kajian tentang Prinsip Keindahan Tari Legong dan Tari Kebyar". Laporan Penelitian. Yogyakarta: Lembaga Penelitian Institut Seni Indonesia Yogyakarta, 1996/1997.

Dana, I Wayan., dan Ni Nyoman Sudewi. "Pelestarian dan Pengembangan Tari Tradisi Bali: Studi Kasus Legong Keraton Peliatan". Laporan Penelitian. Yogyakarta: Lembaga Penelitian Institut Seni Indonesia Yogyakarta, 2010.

Dana, I Wayan. "Membaca Ulang Metode I Mario Mencipta Tari Kebyar" dalam Yudiaryani, et al., (ed). Karya Cipta Seni Pertunjukan. Yogyakarta: JB Publisher bekerja sama dengan FSP ISI Yogyakarta, 2017.

Dibia, I Wayan.Terj. Bergerak Menurut Kata Hati: Metode Baru dalam Menciptakan Tari. Jakarta: MSPI, 2003.

Djelantik, Ayu Bulantrisna (ed). Tari Legong: Dari Kajian Lontar ke Panggung Masa Kini. Denpasar: Dinas Kebudayaan Kota Denpasar, 2015.

Hadi, Y. Sumandiyo. Koreografi: Bentuk - Teknik - Isi. Yogyakarta: Cipta Media, 2011.

Humphrey, Doris. The Art of Making Dances. New York: A Dance Horizons Book, Princeton Book Company, 1959.

Nurhayati, Diah Uswatun. "Gagasan-Gagasan Multikulturalisme Ki Hajar Dewantara dalam Pendidikan Musik Tamansiswa Yogyakarta". Yogyakarta: Disertasi Doktor Penciptaan dan Pengkajian Seni ISI Yogyakarta, 2011.

Reading, Hugo F. Dictionary of Social Sciences, diterjemahkan Sahat Simamora. Kamus Ilmu-ilmu Sosial. Jakarta: CV Rajawali, 1986
Smith, Jacqueline. Dance Composition: A Practical Guide for Teachers (1976), diindonesiakan oleh Ben Suharto. Komposiisi Tari: Sebuah Petunjuk Praktis Bagi Guru.Yogyakarta: IKALASTI, 1985.

Sudewi, Ni Nyoman.’'Legong Keraton Sebagai Seni Pertunjukan, Kontinuitas dan Perubahnanya". Tesis untuk meraih derajat magister bidang ilmu Humaniora, Sejarah Seni, Program Pascasarjana Universitas Gadjah Mada Yogyakarta, 1993.

. "Topeng Legong: Sebuah Tinjauan Historis dalam Konteks Sosial Budaya Masyarakat di Desa Ketewel Bali”. Laporan Penelitian yang dibiayai oleh Institut Seni Indonesia Yogyakarta, 1995.

"Legong Bapang: Sebuah Pengembangan Kreatif Struktur Palegongan". Laporan Penelitian yang dibiayai oleh Institut Seni Indonesia Yogyakarta, 1998.

" "Perkembangan dan Pengaruh Legong Keraton terhadap Pertumbuhan Seni Tari di Bali pada Periode 1920-2005". Disertasi untuk meraih derajat Doktor bidang Pengkajian Seni Pertunjukan, Sekolah Pascasarjana Universitas Gadjah Mada Yogyakarta, 2011.

Suteja, I Kt. Catur Asrama Pendakaian Spiritual Masyarakat Bali dalam Sebuah Karya Tari. Surabaya: Paramita, 2018. 